PRACE GEOGRAFICZNE

zeszyt $154,2018,107-125$

doi: $10.4467 / 20833113$ PG.18.011.9443

Instytut Geografii i Gospodarki Przestrzennej UJ

Wydawnictwo Uniwersytetu Jagiellońskiego

\title{
CZASOPRZESTRZENNY ROZKŁAD RUCHU TURYSTYCZNEGO NA SZCZYCIE ŚNIEŻKI W 2015 ROKU
}

\author{
Mateusz Rogowski
}

\section{Spatiotemporal distribution of visitors on the summit of Śnieżka in 2015}

Abstract: In recent years, there has been an increase in tourism in the most popular mountain areas. A characteristic feature of tourism management in national parks is the recognition of its size. The aim of the study was to investigate the spatiotemporal distribution of visitor flows in the Śnieżka summit area (Karkonosze Mts., SW Poland) in 2015. Mt Śnieżka is the most popular destination in the Karkonosze National Park, as well the highest summit in the Sudety Mts. The data on the number of visitors used in the study originate from the pyroelectric sensors located on all ascending trails to the Śnieżka summit. The analyses revealed that in 2015 there were ca. 650,000 visitors on the summit Śnieżka (460,000 entries recorded by pyroelectric sensors, 46,000 upward adjustment of the above value and 150,000 entries via the cableway from Pec pod Snezkou (Czech Republic). The total visitor load on hiking trails that includes all entries - IN and all exits - OUT in the Śnieżka summit area amounted to about 852,000 . The most popular trail was the "Zakosy" trail with 447,281 visitor load (IN+OUT) and 267,627 visitor entries (IN). More than a half of the tourists reached the Śnieżka summit in the summer, and the month with the highest tourist traffic was August (217,926 IN+OUT). The results can be used to increase the efficiency of the management of tourist traffic in the Śnieżka summit area, one of the most popular tourist destination in the Polish mountains.

Keywords: visitor flow monitoring, Śnieżka, Karkonosze Mts., pyroelectric sensor

Zarys treści: W ostatnich latach widoczny jest coraz większy wzrost ruchu turystycznego w najpopularniejszych obszarach górskich. Znamienne, z punktu widzenia zarządzania turystyką w parkach narodowych, jest rozpoznanie jego wielkości. Celem pracy była czasoprzestrzenna charakterystyka ruchu turystycznego w rejonie szczytu Śnieżki jako najpopularniejszego miejsca Karkonoskiego Parku Narodowego. Do analizy wykorzystano dane z czujników pyro-elektrycznych zlokalizowanych na wszystkich szlakach podejściowych na szczyt. Przedstawione 
dane pozwalają stwierdzić, że w 2015 r. na szczycie Śnieżki zanotowano około 650 tys. wejść (obejmujących około 460 tys. zanotowanych przez czujniki pyro-elektryczne, 46 tys. stanowiących doszacowanie powyższej wartości oraz 150 tys. związanych z wjazdem koleją linową z miejscowości Pec pod Snezkou, Czechy). Całkowita liczba przejść, stanowiąca obciążenie ruchem turystycznym (obejmująca wejścia - IN i zejścia - OUT) na analizowanych szlakach, w rejonie szczytu, wyniosła 852 tys. Najpopularniejszą i najbardziej obciążoną ruchem turystycznym trasą były „Zakosy” (447,281 przejść IN+OUT i 267,627 wejść IN). Ponad połowa turystów zdobyła szczyt w okresie letnim, a miesiącem o największym natężeniu ruchu turystycznego był sierpień (217,926 przejść IN+OUT). Uzyskane wyniki mogą mieć zastosowanie w efektywniejszym zarządzaniu ruchem turystycznym w rejonie szczytu Śnieżki.

Stowa kluczowe: monitoring ruchu turystycznego, Śnieżka, Karkonosze, czujnik pyro-elektryczny

\section{Wprowadzenie}

Karkonosze jako najwyższe pasmo transgranicznego regionu Sudetów są najpopularniejszą destynacją tego obszaru. O ich wybitnej atrakcyjności turystycznej decyduje zdefiniowany przez Wyrzykowskiego (1991) unikatowy krajobraz wysokogórski typu sudeckiego, o ciekawych formach geomorfologicznych, na które składają się rozległe i płaskie partie grzbietowe, liczne i urozmaicone grupy skalne oraz kotły polodowcowe objęte ochroną w postaci parku narodowego i bilateralnego rezerwatu biosfery. Obszar ten zaliczono do I kategorii obszarów krajoznawczych Polski (Wyrzykowski 1986), terenów o podstawowym znaczeniu dla urlopowej turystyki wypoczynkowej (Lijewski i in. 2002).

Karkonoski Park Narodowy odwiedzany jest przez około 2 mln turystów rocznie (Ochrona środowiska, 2016), dzięki czemu był drugim - zaraz po Tatrzańskim -najpopularniejszym parkiem narodowym kraju. W klasyfikacji obszarów chronionych Polski dla potrzeb zagranicznej turystyki przyjazdowej Karkonoski Park Narodowy zaliczono do najwyższej kategorii atrakcyjności turystycznej z dominującym rodzajem walorów o charakterze krajoznawczym (Lijewski i in. 2002).

Śnieżka będąca najwyższym szczytem Karkonoszy i Sudetów (1603 m n.p.m.) została historycznie ugruntowana jako wyróżnik regionu, gdyż od początku notowania ruchu turystycznego była istotnym celem turystów. Szczyt ten stanowi rozpoznawalny symbol kojarzony z naturalnym, historycznym i turystycznym regionem Karkonoszy, ważnym dla Polaków, Czechów i Niemców, co wiązało się z przebiegiem granic wpływów polskich, czeskich, pruskich (niemieckich) i habsburskich (austriackich). Szczyt ten zawsze będzie kojarzony z regionem posiadającym największy potencjał wizerunkowy regionalnego produktu turystycznego (Rogowski 2015). Z tego względu od początku rozwoju turystyki w Sudetach Śnieżka należała do najpopularniejszych miejsc Karkonoszy i Sudetów, odwiedzana niegdyś przez gości i kuracjuszy, a obecnie przez szerokie grono turystów krajowych i zagranicznych oraz uczestników wielu imprez biegowych i marszów długodystansowych. 
Celem pracy była przestrzenna i ilościowa charakterystyka ruchu turystycznego w rejonie Śnieżki w oparciu o dane pozyskane z czujników pyro-elektrycznych w rocznym okresie badawczym (2015 r.) z uwagi na posiadanie danych z najmniejszą liczbą błędów, które zostały skorygowane. $Z$ tego względu, po weryfikacji zebranych danych z czujników pyro-elektrycznych, zdecydowano się objąć analizą dzienny rozkład obejmujący okres 2015 r., pochodzący z trzech urządzeń zainstalowanych na szlakach wejściowych na szczyt: „Zakosy” i „Droga Jubileuszowa” (zamknięta w okresie zimowym ze względu na zagrożenie lawinowe) i żółto znakowany szlak od strony czeskiej. Uszczegółowieniem celu była próba określenia liczby wejść (IN) z uwzględnieniem współczynnika doszacowania, a także przejść (IN+OUT), zdefiniowanego jako obciążenie ruchem turystycznym, w ujęciu miesięcznym, dziennym i godzinowym.

\section{Ilościowy monitoring ruchu turystycznego}

Ilościowy monitoring ruchu turystycznego realizowano przy okazji wielu obszarów i atrakcji w Polsce. Ważnymi pod tym względem pracami były raporty dotyczące frekwencji w atrakcjach turystycznych (Kruczek 2014, 2015, 2016). Taki monitoring odbywał się najczęściej w oparciu o sprzedaż biletów wstępu, dane szacunkowe Głównego Urzędu Statystycznego, pomiar bezpośredni przez ankietera lub z wykorzystaniem czujników ruchu, co dokładniej opisują m.in. Cessford i Muhar (2003). Ma to również zastosowanie dla parków narodowych, szczególnie w obszarach górskich, ze względu na fakt, iż rzeźba terenu w istotny sposób determinuje sieć dróg i ścieżek, a tym samym, poprzez oznakowane szlaki, ruch turystyczny jest skanalizowany. Uwzględniając dodatkowo przebieg granicy parku narodowego, można uzyskać bardziej wiarygodne dane niż w obszarach nizinnych czy wyżynnych.

Spychała i Graja-Zwolińska (2014) wskazują 14 polskich parków narodowych stosujących czujniki pyro-elektryczne. Autorki twierdzą, że sprzęt ten należy do najskuteczniejszych i najbardziej przydatnych urządzeń w codziennym funkcjonowaniu parku. Spośród innych zalet należy wskazać m.in.: swobodę pomiarów bez angażowania dodatkowych osób, łatwość obsługi oraz małą awaryjność. Pozyskane w ten sposób dane dają możliwość ilościowej charakterystyki ruchu turystycznego w parkach narodowych, choć nie w każdym przypadku są one publikowane. W oparciu o dane z czujników pyro-elektrycznych najdokładniej scharakteryzowano ruch turystyczny w następujących górskich parkach narodowych: Tatrzańskim (Fidelus 2010; Hibner 2014; Taczanowska i in. 2015), Babiogórskim (Buchwał, Fidelus 2010), Bieszczadzkim (Prędki 2012) i Gór Stołowych (Rogowski, Małek 2016; Rogowski 2017). Natomiast ilościową analizą ruchu turystycznego w Karkonoskim Parku Narodowym zajmowała się Wieniawska-Raj (2004, 2007, 2010) w oparciu o sprzedaż biletów wstępu. Dane uzyskane z monitoringu ruchu turystycznego mają wszechstronne zastosowanie z uwagi na możliwość ich przedstawienia w różnych odstępach czasowych. Ponadto 
mogą zostać zagregowane $\mathrm{z}$ danymi dotyczącymi monitoringu środowiska przyrodniczego czy opisującymi samych turystów w oparciu o badania sondażowe.

\section{Monitoring ilościowy - metodyka badawcza w rejonie Śnieżki}

Monitoring ilościowy w rejonie Śnieżki odbywał się z wykorzystaniem zainstalowanych przy każdym z trzech szlaków turystycznych czujników pyro-elektrycznych. Urządzenia te, działające na fale podczerwone, zapisują liczbę przejść poprzez zmienność temperatury. Ponadto istnieje możliwość wskazania kierunków przejść (IN wejście, OUT wyjście) oraz określenia sumy przejść. Zbieranie danych polegało na ich odczycie za pośrednictwem aplikacji Eco-link zainstalowanej na urządzeniu mobilnym. Następnie dane te były umieszczane w arkuszu kalkulacyjnym, w którym były porządkowane i poddane analizie. Obecnie, prócz ww., na terenie Karkonoskiego Parku Narodowego istnieje około 30 czujników pyro-elektrycznych zainstalowanych przy ważniejszych szlakach, a docelowo ma zostać utworzony system podobnego typu, jaki funkcjonuje w Parku Narodowym Gór Stołowych (Rogowski, Małek 2016; Rogowski 2017). Ponadto, w czeskiej części parku również zainstalowano czujniki ruchu.

Największym problemem w przypadku danych pozyskanych z czujników pyro-elektrycznych były występujące luki z uwagi na błędy pomiarowe spowodowane trudnymi warunkami atmosferycznymi w grzbietowych partiach Karkonoszy. W szczególności dotyczyło to okresu zimowego, kiedy na powierzchni urządzeń pojawiał się osad atmosferyczny w postaci szadzi czy szronu, które bywają częstymi zjawiskami występującymi w tym obszarze. W 2015 r. liczba i wielkość błędów były najmniejsze, dzięki czemu zostały skorygowane poprzez zastosowanie współczynnika korelacji, przy wykorzystaniu poprawnych danych. Próba oszacowania prawidłowości pomiarów została przedstawiona w dalszej części tekstu.

\section{Analiza zebranych danych}

\section{Zestawienie roczne}

W 2015 r. zanotowano 458576 wejść (IN) na Śnieżkę oraz 852325 przejść (IN+OUT), interpretowanych jako faktyczne obciążenie ruchem turystycznym. Uzyskane w ten sposób wartości są bardzo istotne w kontekście pojemności szlaków turystycznych, które w toku dalszych prac należy określić. Najpopularniejszą trasą i najbardziej obciążoną ruchem turystycznym w 2015 r. była trasa „Zakosy”, na której zanotowano 58\% wszystkich wejść (267 627) oraz około 50\% przejść (447 218). „Drogą Jubileuszową" na Śnieżkę wszedł przeciętnie co czwarty turysta (120 839), a obciążenie 
tej trasy wyniosło 280834 przejść, potwierdzając, że turyści tę trasę traktują częściej jako zejście, podchodząc „Zakosami”.

Najmniej wejść na Śnieżkę zanotowano na szlaku żółtym (od strony czeskiej), co stanowiło w przybliżeniu około 15\% turystów (70 110), a jego obciążenie sięgało 124273 przejść. Uwzględniając poszczególne pory roku, można wskazać, że ponad połowa turystów (55\%) na Śnieżkę weszła w okresie letnim (251974), co piąty (21\%) wiosną (96 798), nieco mniej (17\%) w okresie jesiennym (76 715), a najmniej (7\%) zimą (33 089). Podobny rozkład na pory roku odnosi się do obciążenia ruchem turystycznym (IN+OUT). Największe obciążenie (56\%) było w okresie letnim (480 008), mniejsze (20\%) - wiosną (173 839) i jesienią (16\%; 140 013), natomiast najniższe (7\%) - zimą (58 465).

\section{Zestawienie miesięczne}

Miesięczny rozkład wejść (IN) (ryc. 1) i przejść (IN+OUT) (ryc. 2), z uwzględnieniem poszczególnych tras, umożliwia wyróżnienie sezonowości ruchu turystycznego.

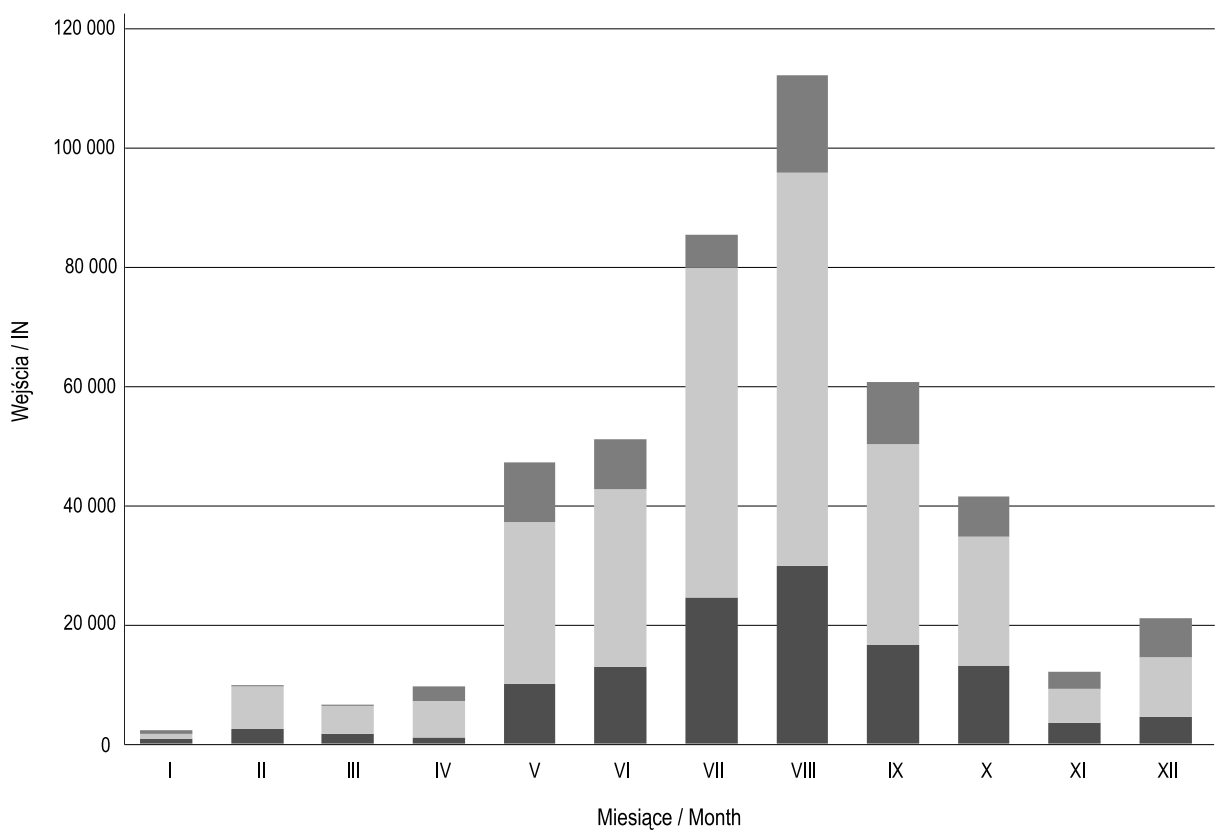

Ryc. 1. Liczba wejść (IN) turystów trasami prowadzącymi na Śnieżkę: ,Jubileuszowa” (ciemnoszary), „Zakosy” (jasnoszary) i szlakiem żółtym od strony czeskiej (ciemnoszary) w 2015 r. Fig. 1. Number of tourists entries (IN) on Śnieżka summit by the „Jubileuszowa” trail (dark grey), "Zakosy" trail (light grey) and yellow marked trail (dark grey) in 2015 


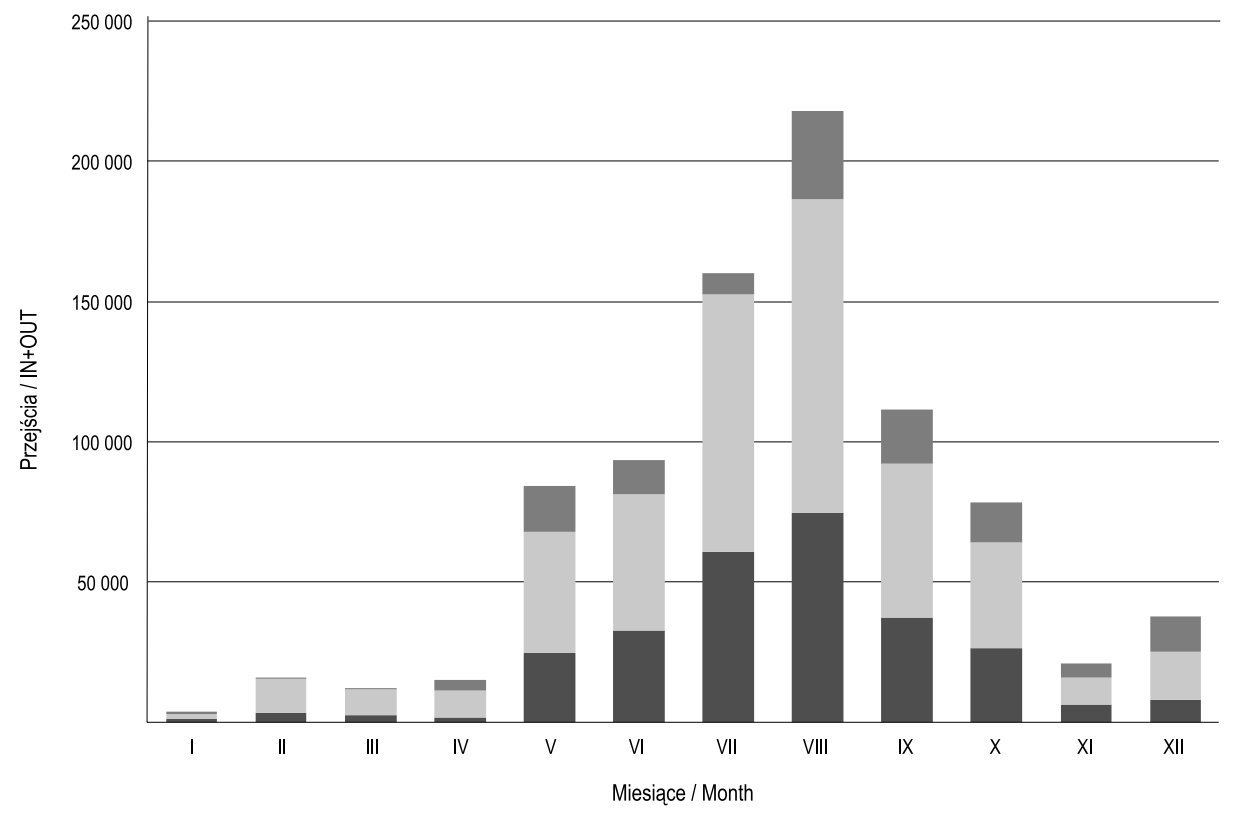

Ryc. 2. Liczba przejść (IN+OUT) turystów trasami prowadzącymi na Śnieżkę: ,Jubileuszowa” (ciemnoszary), „Zakosy” (jasnoszary) i szlakiem żółtym od strony czeskiej (ciemnoszary) w 2015 r.

Fig. 2. Number of tourists passings on Śnieżka summit by the „Jubileuszowa” trail (dark grey), "Zakosy” trail (light grey) and yellow marked trail (dark grey) in 2015

W sierpniu zanotowano największą liczbę wejść (111 963) oraz przejść analizowanymi szlakami (217 926). Następnie w lipcu zanotowano 85363 wejścia i 160232 przejścia. W porównaniu z pozostałymi, oba miesiące można zaliczyć do wysokiego sezonu turystycznego, w których razem zanotowano $43 \%$ wejść oraz $45 \%$ przejść. Niższe wartości wejść i przejść notowane były w okresie jesiennym i wiosennym, co należy potraktować jako średnie sezony, którymi są następujące miesiące:

- wrzesień: 60576 wejść, 111526 przejść;

- czerwiec: 51132 wejścia, 93736 przejść;

- maj: 47271 wejść, 84270 przejść;

- październik: 41365 wejść, 78304 przejścia.

Miesiące te generują kolejne $44 \%$ wejść oraz $43 \%$ przejśc, stanowiąc okresy, w których natężenie ruchu turystycznego jest na średnim poziomie. Pozostałe tworzą niski sezon turystyczny z przeciętną liczbą wejść na poziomie ok. 10 tys. oraz przejść na poziomie około 15-20 tys. Wyjątkiem jest grudzień, w którym wielkość ruchu 


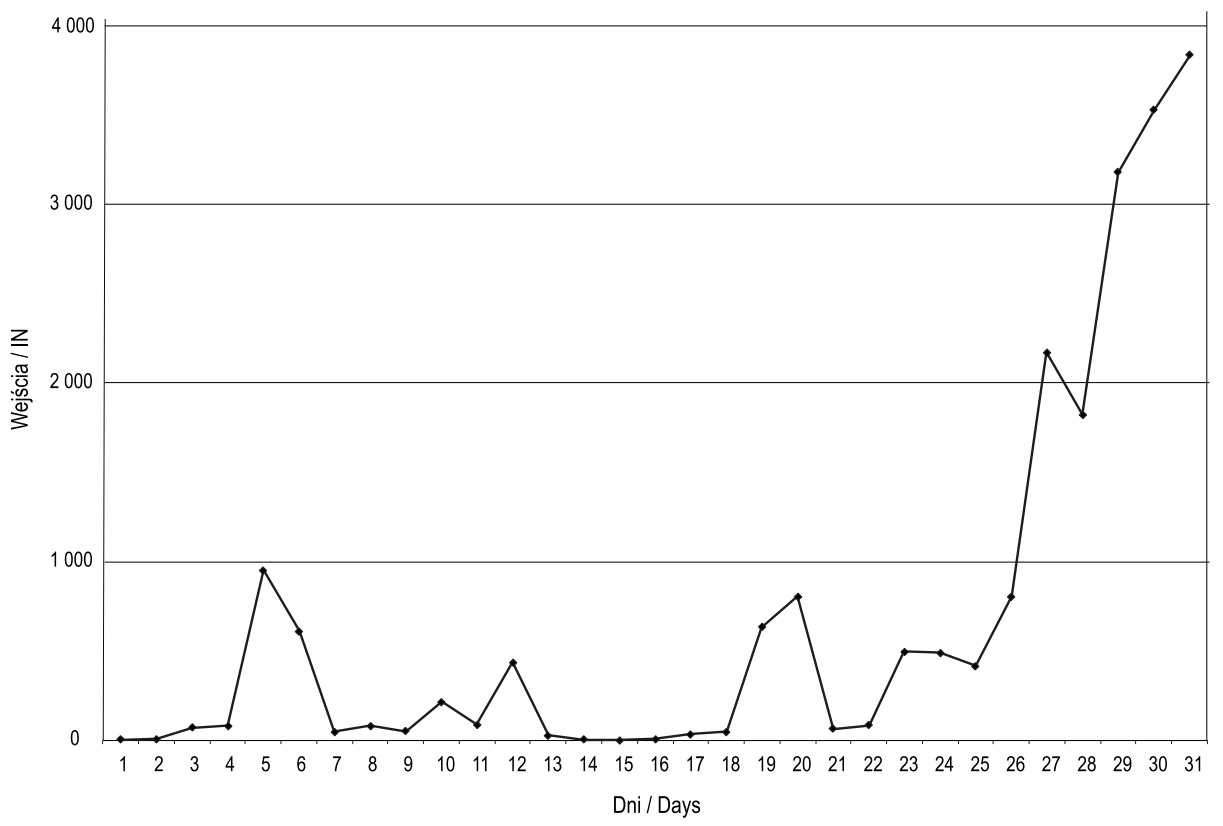

Ryc. 3. Liczba dziennych wejść (IN) na Śnieżkę w grudniu 2015 r.

Fig. 3. Number of daily entries on Śnieżka summit in December 2015

wejściowego osiągnęła wartość 21075 oraz 37981 przejść. Było to spowodowane okresem świąteczno-noworocznym, kiedy w dniach od 24 do 31 grudnia 2015 r. szczyt Śnieżki zdobyło ponad 16 tys. turystów (77\% całości wejść w tym miesiącu) (ryc. 3). Najspokojniejszy pod tym względem był styczeń, w którym zanotowano 2,1 tys. wejść oraz 4 tys. przejść.

Rozkład natężenia ruchem turystycznym w poszczególnych miesiącach ulega niewielkim wahaniom (ryc. 4).

Trasą „Zakosy” każdego miesiąca wchodziło najwięcej turystów, jednak udział w ruchu wejściowym ulegał zmianom (od 39\% w styczniu do 74\% w lutym). Tak duża różnica na przestrzeni dwóch następujących po sobie miesięcy może być spowodowana różniącymi się warunkami turystycznymi - w styczniu trudniejszymi niż w lutym. Udział trasy „Zakosy” w kolejnych miesiącach roku systematycznie maleje na korzyść trasy „Jubileuszowa”. Mimo tego, niemalże w każdym miesiącu trasą „Zakosy” odbywa się przynajmniej połowa podejść (52\% w październiku, 65\% w lipcu). W sierpniu struktura wejść wskazuje, że 59\% odbywa się „Zakosami”, 27\% „Jubileuszową", a 14\% szlakiem czeskim. 


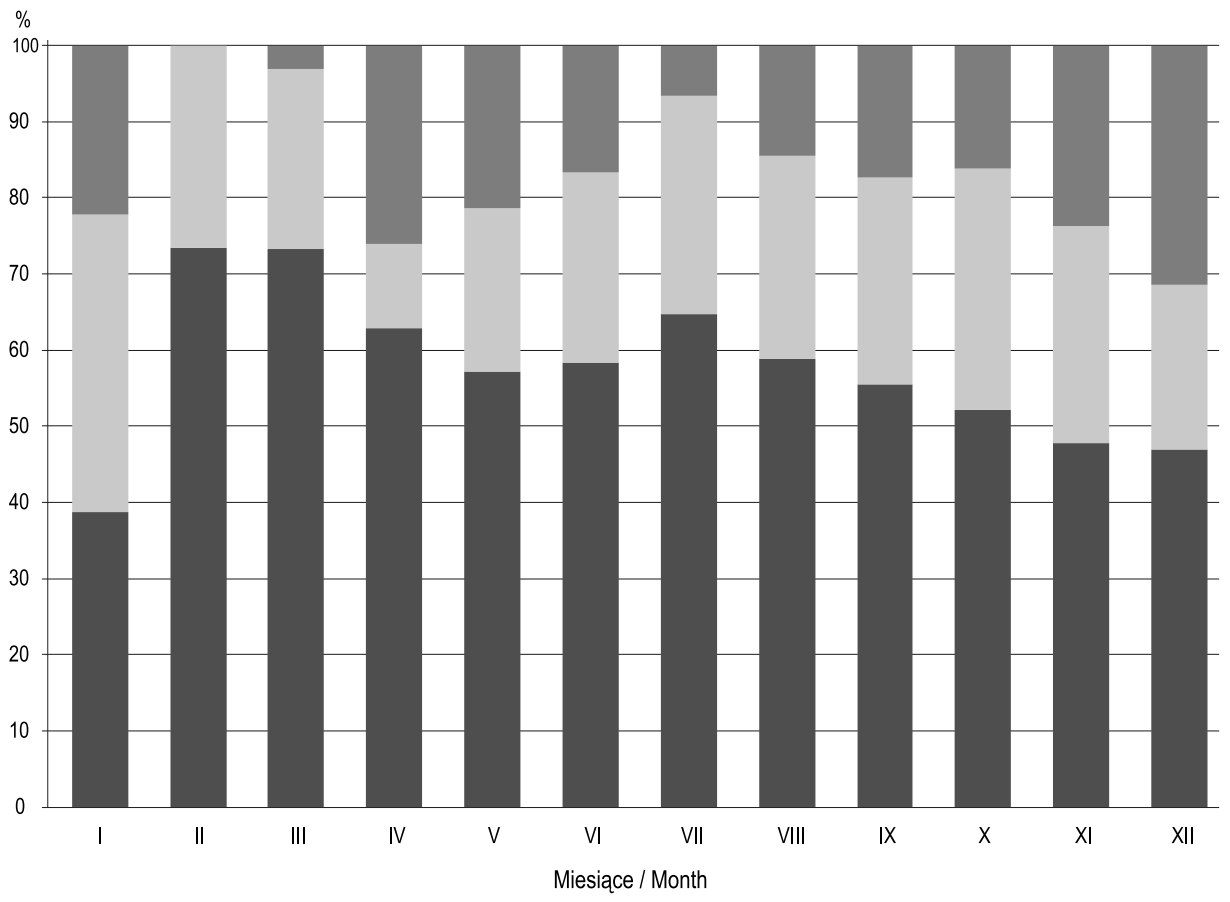

Ryc. 4. Udział tras w ruchu wejściowym na Śnieżkę w 2015 r.: „Jubileuszowa” (ciemnoszary), „Zakosy” (jasnoszary) i szlakiem żółtym od strony czeskiej (ciemnoszary)

Fig. 4. Participation of trails in entries on Śnieżka summit in 2015 by the „Jubileuszowa” trail (dark grey), "Zakosy" trail (light grey) and yellow marked trail (dark grey)

\section{Zestawienie dzienne}

Analizując dzienne wejścia (IN) wszystkimi trasami na Śnieżkę w 2015 r., można wskazać dni z maksymalnymi wartościami w danym miesiącu (ryc. 5).

Zestawienie dziennych wejść wykazuje największą popularność dni wolnych od pracy, najczęściej związanych z długimi weekendami. Ponadto dzienne wejścia potwierdzają podział analizowanego roku na niski, średni i wysoki sezon turystyczny. Niskie wartości mediany i wąski rozkład danych wskazują na niski sezon turystyczny. Jedynie grudzień różni się od miesięcy tego okresu szerszym rozkładem danych i znacznie wyższą wartością maksymalną. Jednakże wartość mediany jednoznacznie wskazuje, że pomimo większej liczby przejść w okresie świąteczno-noworocznym, w tym okresie dominują wartości odpowiadające niskiemu sezonowi turystycznemu. Rozkład danych dla miesięcy średniego sezonu turystycznego jest najszerszy. 


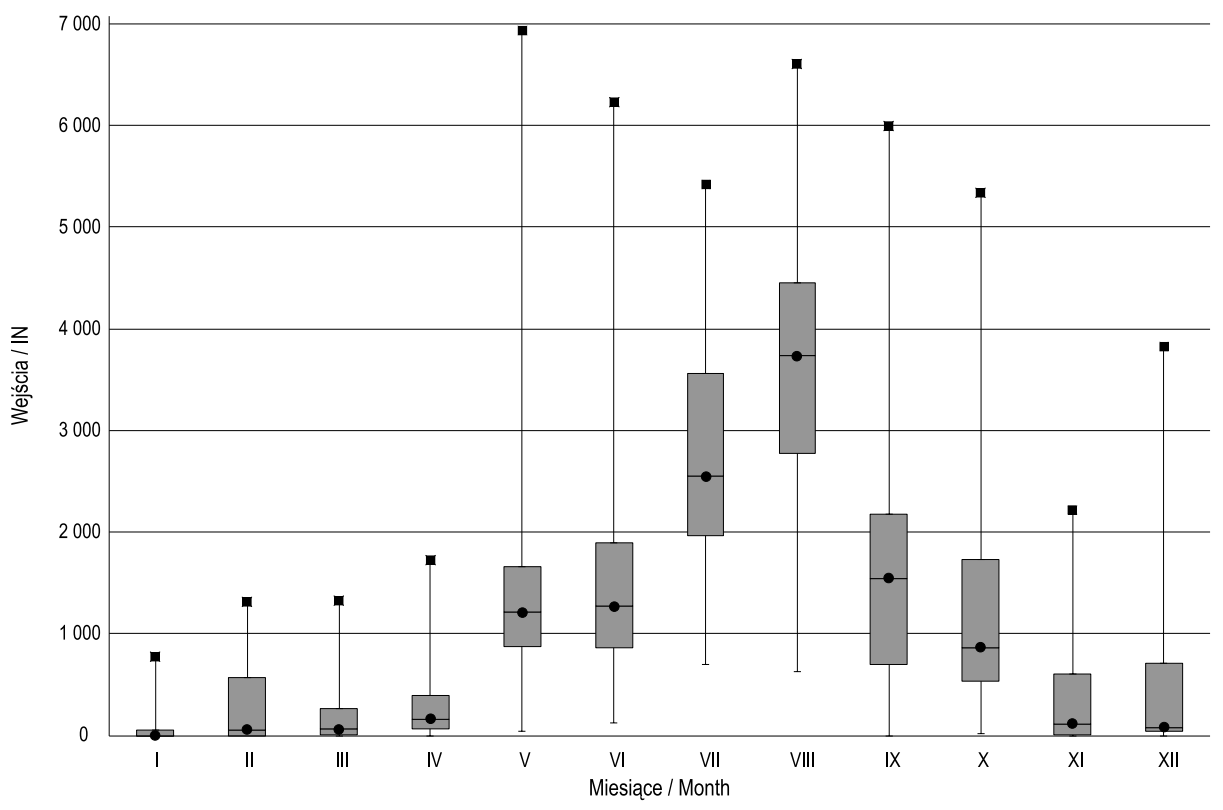

Ryc. 5. Dzienne wejścia wszystkimi trasami na Śnieżkę w 2015 r. (kwadrat: maksimum dla miesiąca; kropka: mediana dla miesiąca)

Fig. 5. Daily entries of every trails on Śnieżka summit in 2015 (square: maximum per month; circle: median per month)

Oznacza to, że dzienna liczba wejść w poszczególnych dniach jest najbardziej zróżnicowana. Przesunięcie median dla kwietnia, maja, września i października w kierunku wartości minimum, wskazuje na skupienie połowy danych w węższym przedziale. Jednocześnie w miesiącach średniego sezonu turystycznego notuje się wysokie roczne maksima dziennych przejść. W maju zanotowano największe dzienne maksimum dziennych wejść, wynoszące 6954, co było związane z wystąpieniem długiego weekendu - 1-3 maja (ryc. 6). Przyjmując, że wejścia odbyły się wyłącznie podczas dnia, można wskazać średnią liczbę wejść wynoszącą 464 osoby w ciągu godziny oraz około 8 osób w ciągu minuty.

Zauważalne jest także duże zróżnicowanie liczby dziennych wejść na Śnieżkę w maju. Można wskazać krótkotrwały wzrost ruchu turystycznego podczas weekendów, natomiast w ciągu tygodnia notowano w przybliżeniu o połowę niższy ruch turystyczny, dla którego minimum przypadało najczęściej w środę. Fakt ten mógł być determinowany dwoma czynnikami. Turyści indywidualni, decydujący się na pobyty weekendowe, przedłużają je o 1-2 dni. Tym samym, środa najrzadziej jest 


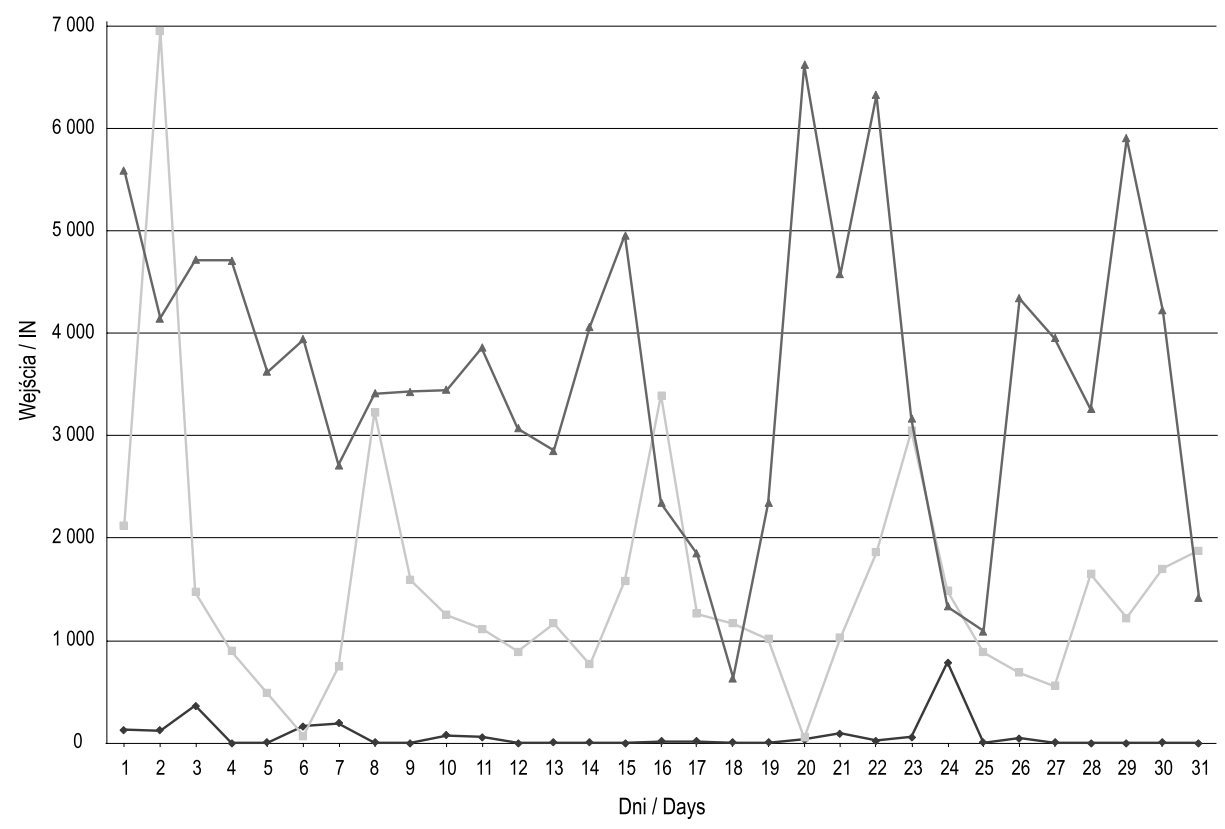

Ryc. 6. Porównanie dziennych wejść na Śnieżkę w styczniu (ciemnoszary - niski sezon), maju (jasnoszary - pośredni sezon) i sierpniu (ciemnoszary - wysoki sezon)

Fig. 6. Comparison of daily entries to Śnieżka summit in January (dark grey - low season), May (light grey - medium season) and August (dark grey - high season)

uwzględniana w tych planach. Drugim czynnikiem były wycieczki szkolne, których największa liczba przypada na maj, trwające najczęściej 3 dni, przy czym środa najczęściej jest dniem przyjazdu lub powrotu. W sierpniu zróżnicowanie liczby dziennych wejść było mniejsze, natomiast ilościowo charakteryzowało się najwyższymi wartościami w roku, co potwierdza wysokość i lokalizacja mediany w rozkładzie danych, a także drugie i trzecie w kolejności najwyższe wartości zanotowane 20 sierpnia (6621) i 22 sierpnia (6326) związane z długim weekendem. W kolejnych dniach frekwencja ruchu turystycznego zaczęła wyraźnie spadać, wskazując na końcówkę wakacji szkolnych.

Dzienne natężenie ruchu turystycznego na wszystkich analizowanych szlakach przedstawia ryc. 7. Najwyższe wartości przekraczają wartość 10 tys. przejść, co ma miejsce każdego miesiąca od maja do października. Najwięcej przejść zanotowano: 20 sierpnia (12 019), 2 maja (11 871), 22 sierpnia (11 830), 19 września (11 565), 5 czerwca (11 485), 6 czerwca (11 419), 29 sierpnia (11 281), 1 sierpnia (10 768) i 4 czerwca (10 536). 


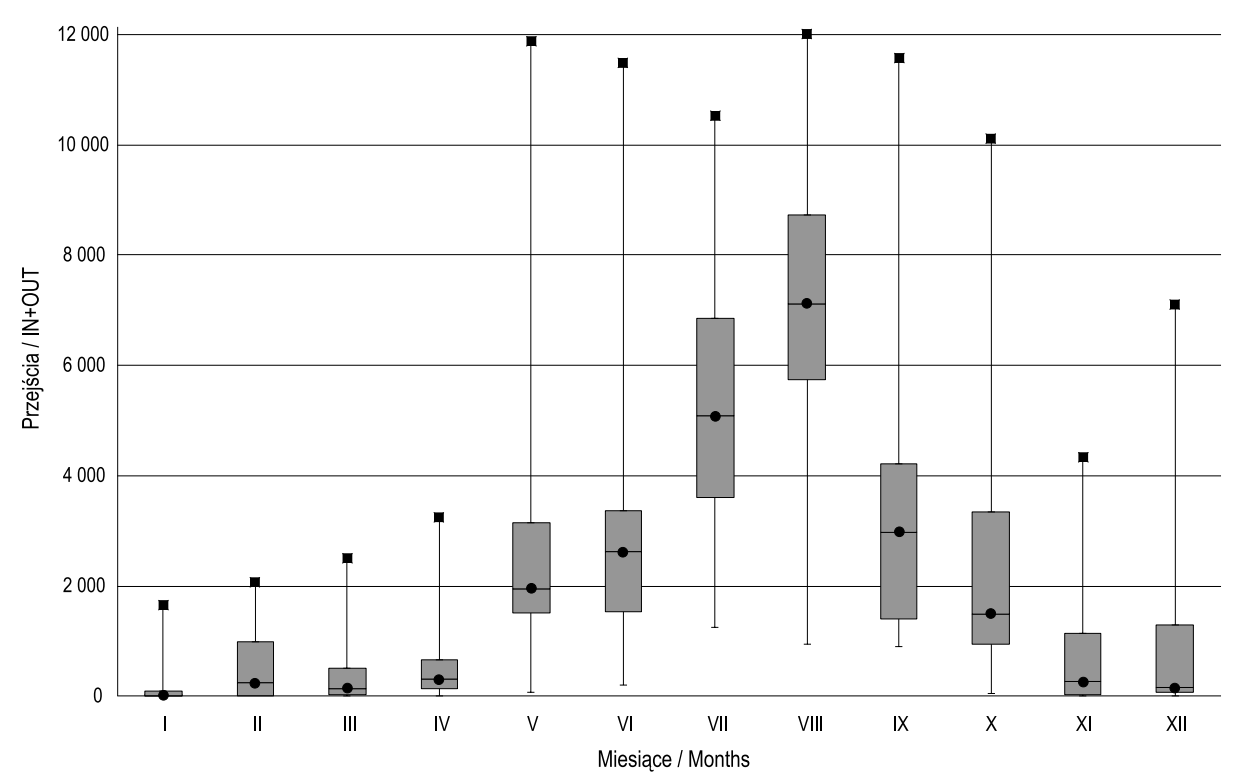

Ryc. 7. Dzienne przejścia (IN+OUT) na szlakach w rejonie Śnieżki w 2015 r.

Fig. 7. Daily passing on trails in Śnieżka summit area in 2015

Mediany oraz wartości pomiędzy drugim a trzecim kwartylem potwierdzają wyróżnienie wysokiego, średniego i niskiego sezonu turystycznego. Zbliżanie mediany do trzeciego kwartyla wskazuje, że w danym miesiącu ruch turystyczny jest duży, w przeciwieństwie do sytuacji, w której mediana mieści się bliżej drugiego kwartyla. Wówczas można mówić, że dany miesiąc jest zaliczany do pośredniego lub niskiego sezonu turystycznego. Wyróżnienie to ponadto potwierdzają wartości maksymalne. Podobnie przedstawiają się dane dla trasy „Zakosy” oraz „Jubileuszowa” (ryc. 8, 9).

Na trasie „Zakosy” notuje się największy ruch turystyczny. Ponadto maksymalne obciążenie ruchem turystycznym (IN+OUT) wystąpiło 22 sierpnia (sobota), wynosząc 6152 przejść. Tego dnia pierwsze przejście zanotowano pomiędzy godzinami 2 a 3 w nocy, a ostatnie pomiędzy 20 a 21. Ruch turystyczny podczas tej doby odbywał się przez 19 godzin, co daje 324 przejścia w ciągu godziny oraz 5 przejść na minutę, z czego przeciętnie były to 3 wejścia (IN) i 2 zejścia (OUT). Cały sierpień charakteryzuje się najwyższą przeciętną wartością dziennego obciążenia ruchem turystycznym (IN+OUT), wynoszącą 3606 przejść. To sprawia, że w tym miesiącu generowana jest 1/4 rocznego ruchu turystycznego. Wysokie wartości dziennych przejść notowano również w lipcu (maksimum 4 lipca w sobotę - 5816 przejść), co potwierdza także przeciętna liczba przejść w tym miesiącu (3249). Porównywalna 


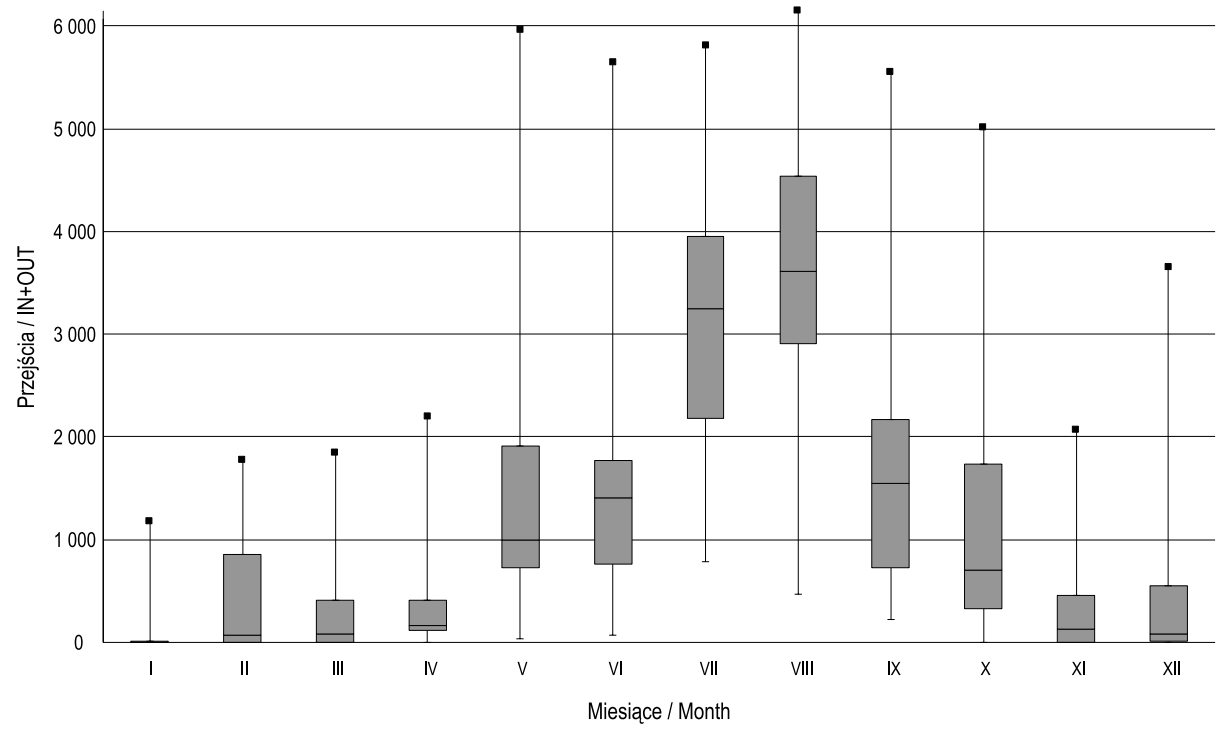

Ryc. 8. Dzienne obciążenie ruchem turystycznym trasy „Zakosy” w 2015 r.

Fig. 8. Daily passing on tourist traffic in "Zakosy" trail in 2015

liczba przejść notowana jest także w czerwcu i we wrześniu. W przypadku tych miesięcy, a także dla maja i października, notowane było wysokie dzienne maksimum osiągające przynamniej 5 tys. przejść, podczas następujących dni: 2 maja, 5, 6 czerwca, 4 lipca, 1, 15, 20 i 29 sierpnia. Warto również podkreślić, że krótkotrwały wzrost liczby przejść zauważalny był w ostatnich dniach grudnia.

Na trasie „Jubileuszowa” notowano przeciętnie o połowę mniejsze obciążenie ruchem turystycznym niż na „Zakosach”. Największy ruch na tym szlaku notowany był w czerwcu i we wrześniu (czyli poza ścisłym sezonem turystycznym). Mogło to być spowodowane trudnymi warunkami atmosferycznymi i turystycznymi, przez co turyści decydowali się na przejście łatwiejszą trasą. Ponadto można przypuszczać, że poza sezonem letnim proporcjonalnie więcej osób wybiera łatwiejszą trasę „Jubileuszową” z powodu wygody, gdyż na Równię pod Śnieżką mogą się dostać kolejką linową, chcąc możliwie najłatwiej osiągnąć szczyt. Natomiast turyści, którzy podchodzili pieszo, częściej kontynuowali podejście trudniejszymi „Zakosami”. Maksymalna liczba przejść trasą „Jubileuszowa” jest o 1/3 mniejsza od przejść „Zakosami” i zanotowano ją w sezonie letnim - 5 czerwca (tzw. długi weekend) i było to 4755 przejść. Następnie zanotowano 4663 przejścia w dniu 19 września (sobota, podczas imprezy „Bieg Dookoła Kotliny Jeleniogórskiej”) oraz 4371 przejść 


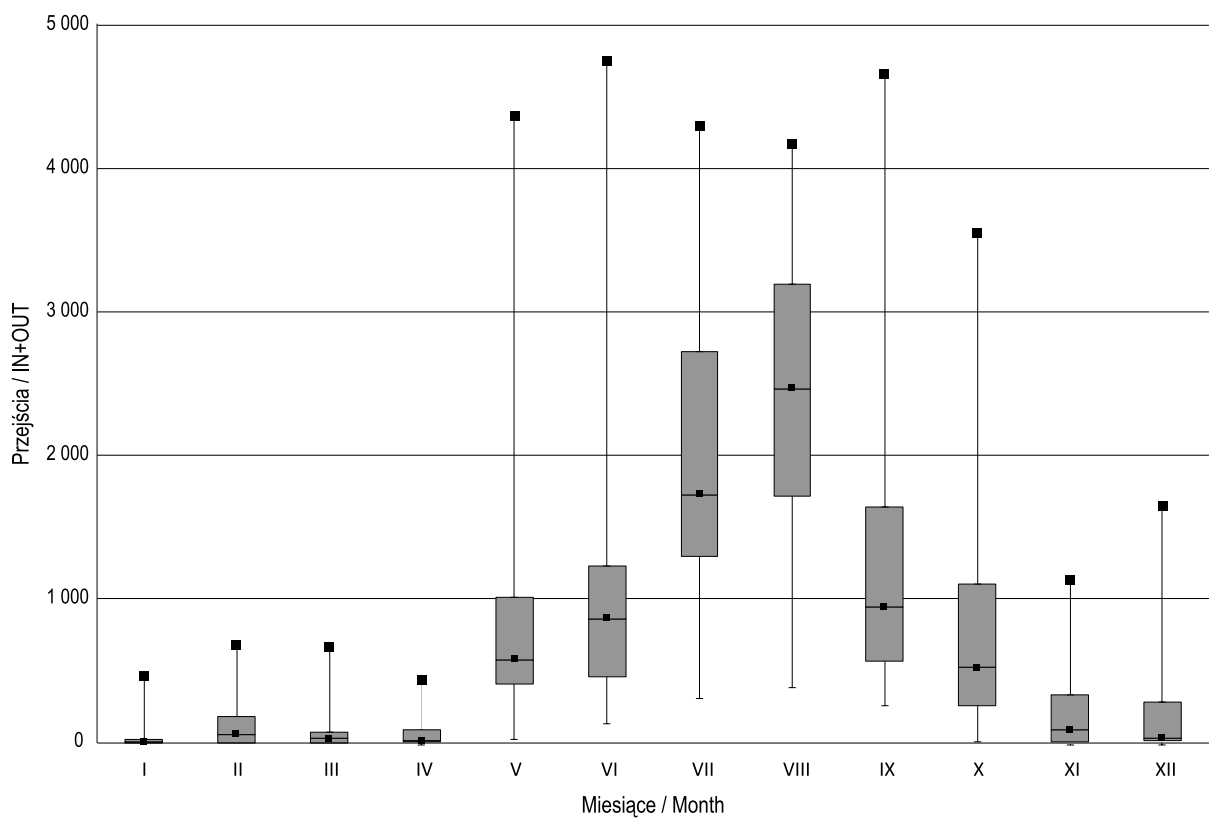

Ryc. 9. Dzienne obciążenie ruchem turystycznym trasy „Jubileuszowa” w 2015 r.

Fig. 9. Daily passing on tourist traffic in "Jubileuszowa" trail in 2015

2 maja. W dalszej kolejności były to wartości notowane podczas letniego sezonu turystycznego: 4 lipca (4299 przejść), 20 sierpnia (4173 przejścia) i 29 sierpnia (4022 przejścia). Natomiast w przypadku przeciętnej liczby przejść w ciągu miesiąca, najwyższy wskaźnik odnotowano w sierpniu (2405 przejść), lipcu (1996 przejść) oraz we wrześniu (1249 przejść), co można interpretować dużą zmiennością liczby przejść w okresie wiosennym i jesiennym.

Minimalne obciążenie ruchem turystycznym (IN+OUT) na analizowanych trasach wystąpiło od stycznia do kwietnia. Mediany dla trasy „Zakosy” były 3 do 5 razy wyższe niż dla trasy „Jubileuszowa”. Niektóre dni charakteryzowały się brakiem przejść, co mogło być spowodowane trudnymi warunkami pogodowymi i terenowymi. Sytuacja ta wystąpiła podczas 18 dni w styczniu, 10 dni w lutym i 9 dni w listopadzie, a także w pojedynczych dniach grudnia, marca i kwietnia. Na „Jubileuszowej” było to 14 dni w styczniu, 10 dni w lutym, 6 dni w listopadzie oraz pojedyncze dni w tych samych miesiącach, co na „Zakosach”. Należy jednak podkreślić, że do tych wyników trzeba podchodzić z dystansem, gdyż może istnieć prawdopodobieństwo, że mogło być to spowodowane zawodnością sprzętu. 


\section{Zestawienie godzinowe}

Godzinowe zestawienia wejść i przejść przygotowano wyłącznie w oparciu o dostępne dane dla tras „Zakosy” i „Jubileuszowa” (tab.1). Pracownicy czeskiego parku narodowego nie udostępnili danych godzinowych dla szlaku żółtego.

Maksymalne natężenie ruchu turystycznego (IN+OUT) na obu analizowanych trasach zanotowano 19 września pomiędzy godziną 12 a 13 i były to 1132 przejścia (773 wejścia, 359 zejść) na trasie „Zakosy” i 1085 przejść (509 wejść, 576 zejść) na „Jubileuszowej”, co dało w przybliżeniu 18-19 przejść w ciągu minuty oraz 1 przejście co około 3 sekundy. Kolejne wysokie wartości notowano również w godzinach popołudniowych (12-14) w poszczególnych dniach maja, sierpnia, lipca, a także 3 października (z powodu bardzo dobrych warunków pogodowych). W przypadku najwyższych wartości liczba przejść trasą „Zakosy” jest przeciętnie o 20-40\% wyższa niż adekwatnych czasowo wartości dla „Jubileuszowej”.

Dodatkowo przedstawiono również zestawienie wejść obiema trasami na Śnieżkę w najpopularniejszym dniu w 2015 r. (ryc. 10). 20\% turystów wówczas weszło

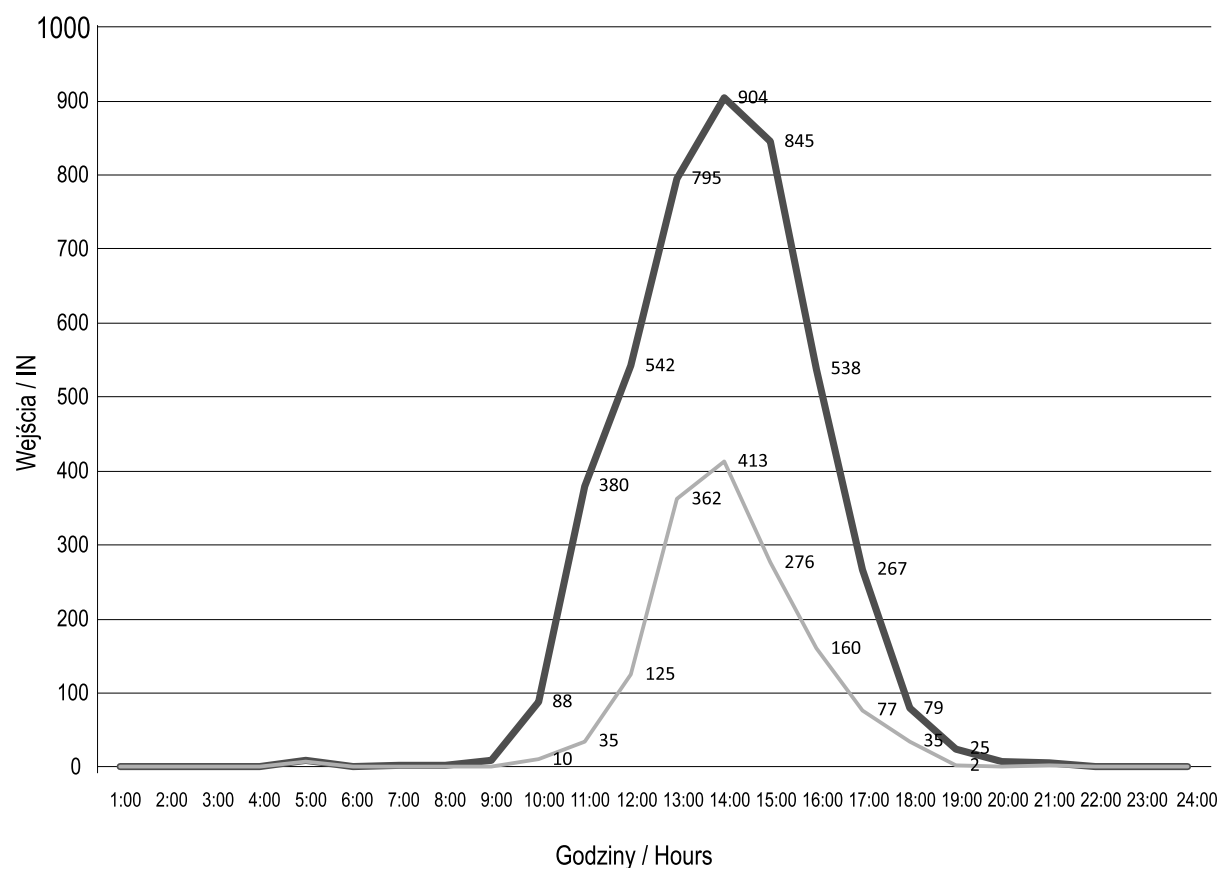

Ryc. 10. Godzinowe wejścia (IN) w dniu 2 maja 2015 r. trasami: „Zakosy” (ciemnoszary) i Jubileuszowa (jasnoszary)

Fig. 10. Daily entries into Śnieżka summit in 2 May 2015 by the "Zakosy" trail (dark grey) and "Jubileuszowa" trail (light grey) 
„Zakosami” pomiędzy godziną 12 a 13. Zbliżone wartości zanotowano w godzinie poprzedzającej, jak i późniejszej. Tym samym widoczna jest wysoka koncentracja ruchu wejściowego w 3-godzinnym okresie (11-14), w którym zanotowano niemalże $60 \%$ wejść. W przypadku „Drogi Jubileuszowej” koncentracja czasowa była jeszcze wyższa. 27\% turystów podchodziło na szczyt pomiędzy godziną 12 a 13, 24\% w godzinie poprzedzającej, a 18\% w godzinie późniejszej. To wskazuje 70-procentową koncentrację ruchu wejściowego w tym samym 3-godzinnym okresie. Dane również pokazują, że turyści podążają na szczyt na wschód słońca, gdyż pomiędzy godziną 3 a 4 zanotowano dziewięć podejść „Zakosami” oraz osiem zejść „Drogą Jubileuszową”.

\section{Wnioski}

Czujniki pyro-elektryczne są coraz częściej wykorzystywanym narzędziem w zliczaniu przejść w różnych obszarach. To pokazuje wszechstronność i aplikacyjność danych w bieżącym monitoringu ruchu turystycznego i zarządzaniu nim nie tylko w obszarach cennych przyrodniczo. W oparciu o zebrane dane można z większą dokładnością określić liczbę wejść (IN), wyjść (OUT) i przejść (IN i OUT) osób w określonych miejscach. Dzięki temu możliwe jest wskazanie popularności poszczególnych atrakcji, bieżącego obciążenia oraz zmienności w różnych odstępach czasowych. Dane te mogą być podstawą dalszych analiz w zakresie pojemności turystycznej szlaków oraz agregacji z wynikami prowadzonych badań sondażowych pośród turystów oraz innych danych.

Jak wynika z literatury przedmiotu, czujniki pyro-elektryczne są urządzeniami dostarczającymi w miarę dokładne dane, należącymi do najdokładniejszych sposobów określania rzeczywistej liczby turystów. Jednakże w wyniku obserwacji bieżącego funkcjonowania tych urządzeń w Górach Stołowych, należy podkreślić, że błąd pomiarowy wskazany przez producenta wynoszący 5\% (Rogowski 2017) jest niedoszacowany. Wynika to głównie z błędnego pomiaru przejść osób idących obok siebie, co jest charakterystyczne dla grup. Na tej podstawie należałoby ustalić i zweryfikować poprzez porównanie ze sobą całkowitej liczby wejść (IN) i przejść (IN+OUT), zanotowanych dla wszystkich szlaków w rejonie Śnieżki. W tym przypadku należy przyjąć, że na analizowanych szlakach zanotowano tożsamą liczbę wejść (IN) i zejść (OUTT), które po zsumowaniu dadzą właściwą liczbę przejść, co będzie podstawą weryfikacji. Zostało to wykonane dla półrocza ciepłego, z wyjątkiem dni z brakiem wskazań pomiarowych (2, 3 i 8 kwietnia). Powyższy wybór był zdeterminowany mniejszą zawodnością sprzętu w półroczu ciepłym oraz większym ruchem turystycznym.

Powyższy histogram wskazuje częstość występowania błędów między właściwą a zarejestrowaną przez czujniki ruchu liczbą przejść. Z ryc. 11 wynika, że 40\% 


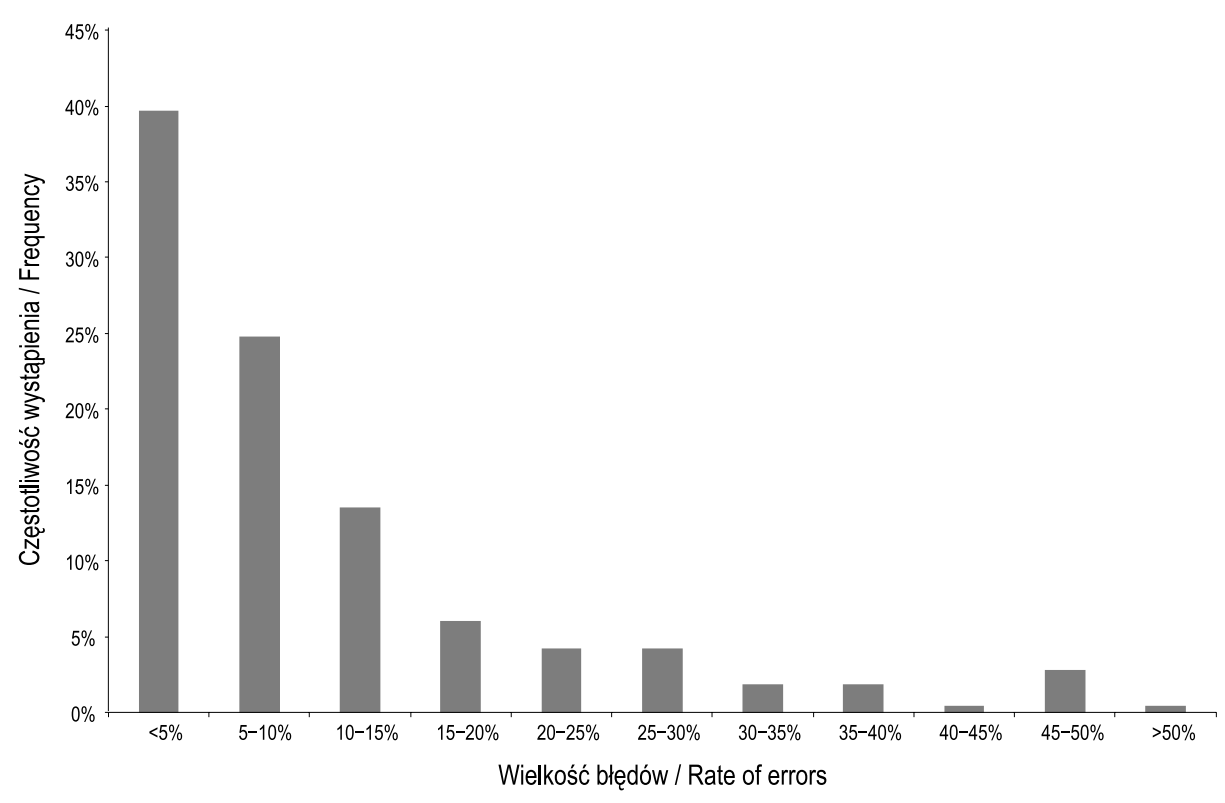

Ryc.11. Histogram wielkości błędów pomiędzy oczekiwaną a zmierzoną liczbą przejść (IN+OUT) dla dni pomiarowych

Fig. 11. The histogram of errors between estimating expected and measured of passing (IN+OUT) for a days

występujących błędów różni się od wartości właściwej o maksymalnie 5\%. Natomiast 2/3 błędów pomiarowych jest mniejsze niż 10\%. To sprawia, że czujniki pyro-elektryczne dostarczają wiarygodnych danych, w przypadku których poziom błędów dla dwóch z trzech wartości jest niższy niż 10\%. Błąd dla 1/3 analizowanych dni jest wyższy od $10 \%$ i najczęściej jest notowany w dniach miesięcy wiosennych i jesiennych (21 dni kwietnia, 17 dni maja, 12 dni czerwca i 9 dni października). Jedynie trzy błędy tej wielkości zanotowano w sierpniu, a siedem w lipcu i wrześniu. Tym samym niskie wartości błędów notuje się w dniach letniego sezonu turystycznego przy intensywniejszym ruchu turystycznym. Podsumowując, należy podkreślić, że przeciętny wskaźnik błędu wyniósł 10\%, a mediana 6\%. W efekcie, współczynnik doszacowania powinien wynieść 10\%, który został uwzględniony w doszacowaniu wielkości ruchu turystycznego w analizowanym obszarze.

W oparciu o powyżej przedstawione dane można wskazać trzy główne wnioski: 1. W 2015 r. na Śnieżce przebywało około 650 tys. osób, co czyni ją jedną z najpopularniejszych gór i atrakcji w Polsce, a nawet w tej części Europy. Na liczbę tę składają się zarówno dane uzyskane z czujników pyro-elektrycznych 
zamontowanych przy analizowanych szlakach (460 tys. wejść), doszacowane wskaźnikiem błędu (46 tys.) oraz turyści korzystający z kolei linowej z miejscowości Pec pod Snezkou, których w 2015 r. było około 150 tys. Przy uwzględnieniu tych wartości przeciętna dzienna liczba turystów, którzy przebywali na szczycie, wyniosła w przybliżeniu 1780 osób.

2. Rozkład miesięcznych i dziennych danych wejściowych (IN) oraz obciążenia ruchem turystycznym (IN+OUT) umożliwia wyznaczenie niskiego, średniego i wysokiego sezonu turystycznego. Do wysokiego sezonu turystycznego zalicza się lipiec i sierpień, kiedy zanotowano niemalże połowę wejść. Natomiast przeciętna liczba miesięcznych wejść wyniosła około 100 tys. Na pośredni sezon turystyczny składają się maj, czerwiec oraz wrzesień i październik z przeciętną liczbą wejść na poziomie ok. 50 tys. miesięcznie. Wartym podkreślenia jest fakt, że najbardziej obciążony turystycznie w tym okresie był wrzesień, mimo że czerwiec, wydawać by się mogło, jest korzystniejszy z uwagi na dłuższe dni. Niskim sezonem turystycznym jest półrocze zimowe (okres od listopada do kwietnia) z przeciętną liczbą ok. 10 tys. wejść miesięcznie, z wyjątkiem grudnia, w którym wartość ta osiągnęła 21 tys., za sprawą okresu świąteczno-noworocznego.

3. Najbardziej obciążonym i najpopularniejszym wejściem na Śnieżkę jest trasa „Zakosy”, którą wchodzi przeciętnie połowa turystów. Co czwarty z nich wszedł trasą „Jubileuszową”, a kolejnych 15\% szlakiem żółtym od strony czeskiej. W związku z tym, należałoby opracować i wyznaczyć pod tym względem wskaźnik pojemności turystycznej badanych szlaków - w szczególności najbardziej obciążonego - by wyznaczyć okres i miejsce przekroczenia tego wskaźnika. Zważywszy jednak na obecnie występujący ruch turystyczny w tym obszarze, należy podkreślić, że ma on charakter wybitnie masowy, sprawiając, że ustalone wskaźniki mogą być przekraczane. Określenie takiego wskaźnika dałoby podstawę do sprawdzenia, czy konieczna jest reorganizacja ruchu turystycznego w rejonie Śnieżki.

Podsumowując, należy stwierdzić, że pomimo występującego błędu pomiarowego (na poziomie 10\%) dane uzyskiwane z czujników pyro-elektrycznych należą do najbardziej wiarygodnych pomiarów pozyskiwanych za pomocą sprzętu. Większą wiarygodnością cechowałyby się dane z ręcznego zliczania turystów, jednak dla tak długiego okresu badawczego byłoby to czaso- i pracochłonne. Dane uzyskane z czujników pyro-elektrycznych dają obraz popularności i bieżącego obciążenia ruchem turystycznym szlaków, stanowiąc podstawę do określenia wskaźnika pojemności turystycznej. Ponadto, dane te mogą być zestawiane z innymi, służąc dokładnej charakterystyce ruchu turystycznego w analizowanym obszarze oraz umożliwiając wskazanie przyczyny i stopnia negatywnych przeobrażeń krajobrazu.

Badania finansowane z Funduszu Leśnego

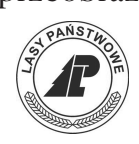




\section{Literatura}

Buchwał A., Fidelus J., 2010, Monitoring ruchu turystycznego przy użyciu czujników ruchu na przyktadzie Tatrzańskiego i Babiogórskiego Parku Narodowego, [w:] Z. Krzan, Nauka a zaræqdzanie obszarem Tatr i ich otoczeniem. Ciztowiek $i$ Środowisko, Materiały IV Konferencji: Przyroda Tatrzańskiego Parku Narodowego a człowiek, t.3, Tatrzański Park Narodowy, Zakopane, $45-54$.

Cessford G., Muhar A., 2003, Monitoring options for visitor numbers in national parks and natural areas, Journal for Nature Conservation 11, 240-250.

Fidelus J., 2010, Porównanie skutków przeksztatceń rzę́by pod wptywem antropopresji w polskiej i stowackiej części Tatr Zachodnich, Prądnik. Prace i Materiały Muzeum im. Prof. Władysława Szafera, 20, 185-196.

Hibner J., 2014, Monitoring ruchu turystycznego w rejonie Kasprowego Wierchu - metody i problemy badawcze, Współczesne Problemy i Kierunki Badawcze w Geografii, 2, Uniwersytet Jagielloński, Kraków, 33-47.

Kruczek Z., 2014, Frekwencja w atrakcjach turystycznych, Polska Organizacja Turystyczna, Warszawa-Kraków.

Kruczek Z., 2015, Analiza frekwencji w polskich atrakcjach turystycznych, Turyzm, 25/1, 47-55.

Kruczek Z., 2016, Frekwencja w atrakcjach turystycznych w latach 2011-2015, Polska Organizacja Turystyczna, Warszawa-Kraków.

Lijewski T., Mikułowski B., Wyrzykowski J., 2002, Geografia turystyki Polski, Polskie Wydawnictwo Ekonomiczne, Warszawa.

Ochrona Środowiska 2016, Główny Urząd Statystyczny, Warszawa.

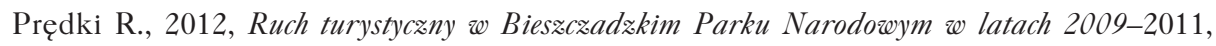
Roczniki Bieszczadzkie, 20, 358-377.

Rogowski M., 2015, Preferencje turystów w polskich Karkonoszach jako podstawa tworzenia produktu turystycznego obsæaru, Rozprawy Naukowe Akademii Wychowania Fizycznego, 50, 152-163.

Rogowski M., Małek B., 2016, Monitoring ruchu turystycznego w Parku Narodowym Gór Stotowych, [w:] Z. Młynarczyk, A. Zajadacz, (red.), Uwarunkowania i plany rozwoju turystyki. Turystyka przyrodnicza i uwarunkowania jej rozwoju, Turystyka i Rekreacja - Studia i Prace, Uniwersytet im. Adama Mickiewicza, Poznań, 18, 79-97.

Rogowski M., 2017, System Monitoringu ruchu turystycznego (SMrt) w Parku Narodowym Gór Stołowych-założenia i wybrane wyniki, Studia i Materiały Centrum Edukacji Przyrodniczo-Leśnej Rogów, 52, 158-165.

Spychała A., Graja-Zwolińska S., 2014, Monitoring ruchu turystycznego w parkach narodowych, Barometr Regionalny. Analizy i prognozy, 4, 38, 171-177.

Taczanowska K., Zięba A., Brandenburg C., Muhar A., Preisel H., Zięba S., Krzeptowski J., Hibner J., Makaruk W., Sost-Mann H., Latosińska B., Graf C., Benitez R., Bolos V., Gonzalez L.M., Garcia X., Toca-Herra J.L., Ziobrowski S., 2015, Cæasoprzestrzenny rozktad ruchu w rejonie koputy Kasprowego Wierchu w sezonie letnim 2014, [w:] A. Chrobak, 
T. Zwijacz-Kozica (red.), Nauka Tatrom, t. III, Człowiek i Środowisko, Tatrzański Park Narodowy, Polskie Towarzystwo Przyjaciół Nauk o Ziemi - Oddział Krakowski, Zakopane, 127-136.

Wieniawska B., 2004, Socjologiczna analiza ruchu turystycznego na terenie Karkonoskiego Parku Narodowego, Opera Corcontica, 41, 537-544.

Wieniawska-Raj B., 2007, Dynamika ruchu turystycznego w Karkonoskim Parku Narodowym, [w:] J. Štursa, R. Knapik (red.), Geoekologické problémy Krkonǒ̌, Sborn. Mez. Věd. Konf., říjen, 2006, Svoboda n. Úpou, Opera Corcontica, 44/2: 593-602.

Wieniawska-Raj B., 2010, Dynamika ruchu turystycznego w Karkonoskim Parku Narodowym, Opera Corcontica, 47 (supl. 1): 269-276.

Wyrzykowski J. (red.), 1991, Ocena krajobrazu Polski w aspekcie fiæjonomicænym na potræeby turystyki, Wrocław.

Wyrzykowski J, 1985, Studia nad ocenq walorów krajobrazowych Sudetów dla potræeb turystyki,

Monografie; 209, Akademia Wychowania Fizycznego, Poznań.

Mateusz Rogowski

Katedra Turystyki i Rekreacji

Uniwersytet im. Adama Mickiewicsa

ul. Dziegielowa 27, 61-680 Poznań

mateusz.rogowski@amu.edu.pl 
